\title{
Taxation of Foreign Profits with Heterogeneous Multinational Firms
}

\author{
Johannes Becker
}

CESIFO WORKING PAPER No. 2899

CATEgORY 1: Public FinANCE

DECEMBER 2009

\footnotetext{
An electronic version of the paper may be downloaded

- from the SSRN website:

- from the RePEc website:

- from the CESifo website: 


\title{
Taxation of Foreign Profits with Heterogeneous Multinational Firms
}

\begin{abstract}
Recent empirical studies find that foreign direct investment (FDI) by a multinational firm is not associated with a reduction of the firm's domestic activities. As it is often argued, this finding may imply that a country should not tax the firm's foreign profit income since this reduces foreign investment without benefitting the domestic economy. The paper analyzes this argument using a model with heterogeneous multinational firms which serve a foreign market through exports or FDI. If a firm switches from exporting to FDI, domestic activity and tax payments may decrease, stay constant or even rise due to intra-firm trade. It turns out that, in all three cases, the optimal tax system implies full taxation after deduction of foreign tax payments. If the country accounts for the effects of its policy on the foreign price level, the case for taxing foreign income becomes even stronger. From a global point of view, the nationally optimal tax rate on repatriated foreign profits is inefficiently high. In contrast to the standard literature, the globally optimal tax system requires a lower tax rate than under the tax credit system which, under certain circumstances, may imply exempting foreign income from tax.
\end{abstract}

JEL-Code: H25, F23.

Keywords: corporate taxation, foreign profits, multinational firms.

\author{
Johannes Becker \\ Max Planck Institute for Intellectual Property, \\ Competition and Tax Law \\ Marstallplatz 1 \\ 80539 Munich \\ Germany \\ johannes.becker@ip.mpg.de
}

This version: 19th December 2009

I thank May Elsayyad, Clemens Fuest, Andreas Haufler, Frank Stähler and participants at seminars in Munich for valuable comments. 


\section{Introduction}

In 2008, the worldwide income from outward foreign direct investment reached an all-time high of US $\$ 1,283$ billion, of which the United States alone had US\$ 350 billion and the United Kingdom around US\$ 130 billion. $^{1}$ This income is generally taxed at source, i.e. in the country where the investment has been made. However, when transferred back to the firm's headquarter, it can additionally be taxed by the country where the headquarter of the multinational firm resides. In this case, the OECD recommends choosing among two standard systems of taxing repatriated business income: the tax credit system where foreign income is taxed at the domestic corporate tax rate and foreign taxes are credited against the domestic tax liability, and the exemption system where foreign income is exempt from domestic taxation. Given the scarcity of public funds, one would expect that governments in residence countries around the world grasp this opportunity and exercise their right to tax. However, the opposite can be observed: Several countries including the United Kingdom ${ }^{2}$ and the United States ${ }^{3}$ have recently switched from the tax credit system to exemption or are considering such a move.

These reform initiatives receive intellectual support from the academic realm which may seem surprising because, for a long time, scholars used to favor the tax credit system for effiency reasons. However, as proponents of the exemption system argue, empirical findings have altered the view on international capital flows and, thus, the foundation for optimal taxation reasoning. According to these authors, the new view on multinational investment implies the optimality of the tax exemption system. For instance, Mihir Desai (2009) states that "modern welfare norms that capture the nature of multinational firm activity recommend a move toward not taxing the foreign activities of American firms, rather than taxing them more heavily". In this paper, I examine whether the case for switching to an exemption system is theoretically well-founded.

The superiority of the credit system builds on the classical work by Peggy Musgrave (née Richman, 1963) who describes a world in which a multinational firm al-

\footnotetext{
${ }^{1}$ See www.unctad.org (World Investment Report), www.bea.gov and www.statistics.gov.uk (number for UK from 2007: GBP 89,855 (exchange rate from 31/12/2008).

${ }^{2}$ See e.g. HM Treasury and HM Revenue and Customs, 2007.

${ }^{3}$ See e.g. United States Department of the Treasury, Office of Tax Policy, 2007.
} 
locates its investment projects across locations. At the margin, it chooses between investing the last dollar at home or abroad. In such a situation, full taxation of foreign income after deduction of foreign taxes paid is the optimal tax policy from a national point of view, whereas crediting foreign taxes against domestic taxes leads to global optimality. Musgrave's work (Richman, 1963, Musgrave, 1969) and the following contributions like Hamada (1966) and Feldstein \& Hartman (1979) were highly influential in shaping international taxation agreements like e.g. the OECD convention on double taxation treaties. ${ }^{4}$

This view has recently been challenged. The main point of criticism focusses on the multinational's investment behaviour. In the Musgrave model, one dollar of investment abroad crowds out one dollar of investment at home. Proponents of the new view on international taxation argue that this has been proven wrong by empirical evidence. ${ }^{5}$ Instead, a dollar invested abroad can be shown to effectively increase domestic investment within the firm or, at least, to leave it unaffected. ${ }^{6}$ Then, the proponents argue, there is no rationale anymore for taxing foreign income for efficiency reasons. Optimality implies exemption of foreign profits.

In the following, I will restate the proponents' arguments in a formal model which captures the important features of the "nature of multinational firm activity": imperfect competition, firm-specific advantages and heterogeneous consumer tastes. Firms may choose between foreign direct investment, exporting or not servicing the foreign market at all. Firm heterogeneity allows endogenously determining these decisions (as well as those on quantity and prices) as a function of factor productivity, like in Helpman et al. (2004). If the firm chooses investment abroad, part of the production remains at the domestic headquarter and is supplied to the foreign affiliate via intra-firm trade, like in Grossman \& RossiHansberg (2008). As a consequence, foreign investment may actually be associated with increased domestic activity and tax payments. In this case, according to the authors favoring the exemption system, a tax on foreign profits unnecessarily reduces the multinational's firm activity without benefitting (or even by harming) the domestic economy. The model presented in this paper allows asking whether

\footnotetext{
${ }^{4}$ Other standard references are Bond \& Samuelson (1989) and Bucovetsky \& Wilson (1991).

${ }^{5}$ See e.g. Desai \& Hines (2003, 2004), Hines (2008), Desai (2009).

${ }^{6}$ See e.g. Egger \& Pfaffermayr (2003), Simpson (2008), Desai, Foley \& Hines (2009) and Kleinert \& Toubal (forthcoming).
} 
this view is correct and how the choice of the optimal tax rate on foreign profits looks like in such a setting.

As the main result, the model shows that, even if foreign investment increases domestic activity and tax payments, a tax on foreign income is optimal for efficiency purposes. It turns out that the standard result proves to be robust in this setting: The nationally optimal tax system implies full taxation after deduction of foreign tax payments. The reason is that firms themselves take into account that domestic profits increase in response to foreign investment. Without a full tax on foreign income, social and private interests diverge. Moreover, I find that, if the home country is able to manipulate the foreign price level, the incentive to levy a tax on foreign profits may even increase. ${ }^{7}$ From a global point of view (i.e. accounting for the welfare of the foreign country's household), the tax rate on foreign profits is inefficiently high. In contrast to the standard literature, the globally optimal tax system may imply exemption of foreign income.

In order to set the contribution of this paper in a wider context, it is useful to consider how the literature on optimal foreign profit taxation evolved after the seminal achievement by Peggy Musgrave (1963). Essentially, the literature has dealt with a number of extensions concerning the assumption of a fixed capital stock (Horst, 1980, Keen \& Piekkola, 1997), the implementation of double taxation agreements in a strategic multi-country setting (e.g., Janeba, 1995, Mintz \& Tulkens, 1996, and Davies, 2003), the role of deferral (Dharmapala, Foley \& Forbes, 2009) and headquarter mobility (Voget, 2009). Moreover, the implications of alternative forms of investment like r\&d spending (Grubert \& Mutti, 1995) and mergers and acquisitions (Desai \& Hines, 2003, 2004, Becker \& Fuest, forthcoming) have been considered. For the purpose of this paper, extensions regarding the multinational firm's investment behaviour and the introduction of a world capital market are most important. If a country is small relative to the world capital market, capital is virtually infinitely available at a fixed interest rate. Then, investment abroad need not be associated with reduced investment at home, as both investment levels are effectively determined by the world market interest

\footnotetext{
${ }^{7}$ Accounting for tax effects on the foreign price level may capture the case in which foreign and domestic investment are complementary within the firm (as in Desai, Foley \& Hines, 2005) but are substitutes in aggregate (as demonstrated by Feldstein, 1995) because foreign investment by one firm crowds out activity by other firms.
} 
rate. In this setting, there is no need to tax foreign income for efficiency reasons (see Grubert \& Mutti, 1995, Mintz \& Tulkens, 1996, and Devereux, 2004, for a discussion). ${ }^{8}$ However, these studies (implicitly) assume perfect competition and, thus, miss some features of multinational firm activity which have been stressed by recent empirical studies.

Given the literature with its broad range of assumption sets and modelling choices, the question arises which model to choose in order to answer the research question brought up by the recent debate on switching to the exemption system. I have two answers to this question. Firstly, the model should capture all the stylized facts which the exemption proponents have indicated to be crucial for their argument and which the recent empirical studies have proven to be robust. These are firm heterogeneity, imperfect competition and the simultaneous existence of exporting and FDI. The model should yield that domestic activity may react positively to foreign investment within the firm (Desai, Foley \& Hines, 2005), and negatively in aggregate (Feldstein, 1995). Secondly, the proponents of the exemption system themselves recommend a model framework in the tradition of Melitz (2003) for deriving optimal tax rates on foreign income: "This new evidence (...) suggests that further explorations of the application of these models to the question of taxing foreign profits would be highly profitable" (Desai, 2009, p. 11/12). It turns out, though, that a Melitz (2003) framework with FDI, as in Helpman et al. (2004) cannot replicate the stylized fact that domestic activity increases in response to foreign investment. Therefore, I adopt model features from Grossman \& Rossi-Hansberg (2008) where the multinational firm is allowed to allocate different production "tasks" across locations within the firm. This gives rise to intra-firm trade and links the two activity levels at home and abroad with each other.

The remainder of the paper is organized as follows. In the next section, I present the model and the results for nationally and globally optimal tax policy. Section 3 discusses potential extensions and limitations of the analysis. Section 4 concludes.

\footnotetext{
${ }^{8}$ This is true, as long as the domestic tax rate is assumed to be given and no revenue requirement is binding. If the domestic tax rate is endogenized, the government faces a Ramsey style problem of optimization where optimal tax rates on domestic and foreign income reflect the locational elasticities.
} 


\section{The model}

As indicated above, the model used in this paper has two building blocks, the first adopted from Melitz (2003) and Helpman et al. (2004), the second from from Grossman \& Rossi-Hansberg (2008). The integration of these two model types becomes necessary because of the tax focus in this paper which will be clarified later on.

Consider a world with two countries labelled home $(h)$ and foreign $(f)$. In each of these two countries, there are a representative household and many heterogeneous firms.

\subsection{Households}

The representative consumers in the home and the foreign country derive utility $U_{h}$ and $U_{f}$, respectively, from a numéraire good $y$ and a variety of differentiated goods $X$. The differentiated goods are either produced in the home country, then denoted as $x_{h}$ with index $i$, or in the foreign country, denoted as $x_{f}$ with index $j$. To keep things simple, I assume that the household preferences in both countries are equal. Therefore, location indices for representative consumers are omitted until misunderstandings may arise.

The utility function is given by

$$
U=y+\frac{1}{\gamma}\left(\int_{0}^{N_{h}} x_{h}(i)^{\frac{\sigma-1}{\sigma}} d i+\int_{0}^{N_{f}} x_{f}(j)^{\frac{\sigma-1}{\sigma}} d j\right)^{\frac{\sigma}{\sigma-1} \gamma}
$$

where $\gamma$ and $\sigma$ are preference parameter, $N_{h}$ and $N_{f}$ are the numbers of home and foreign produced varieties, respectively, and $\sigma>1$. I further assume that $\frac{\sigma-1}{\sigma}>\gamma$ which ensures that each first derivative of (1) with respect to $x_{h}(i)$ and $x_{f}(j)$ describe a utility maximum (see Chor, 2009, for a similar modelling strategy).

The budget constraint is given by

$$
I=y+\int_{0}^{N_{h}} p_{h} x_{h}(i) d i+\int_{0}^{N_{f}} p_{f} x_{f}(j) d j
$$


where $I$ denotes the household's after-tax income which is the sum of wage income, after-tax profits of firms and lump-sum transfers from the government. Prices are given by $p_{h}, p_{f}$ and unity for the numéraire good $y$. I assume that all home firms belong to the home country's representative household and all foreign firms to the foreign household.

Substituting the budget constraint into the utility function yields

$$
\begin{aligned}
U= & I+\frac{1}{\gamma}\left(\int_{0}^{N_{h}} x_{h}(i)^{\frac{\sigma-1}{\sigma}} d i+\int_{0}^{N_{f}} x_{f}(j)^{\frac{\sigma-1}{\sigma}} d j\right)^{\frac{\sigma}{\sigma-1} \gamma} \\
& -\int_{0}^{N_{h}} p_{h} x_{h}(i) d i-\int_{0}^{N_{f}} p_{f} x_{f}(j) d j
\end{aligned}
$$

The profit-maximizing quantities of $x_{h}(i)$ and $x(j)$ can be written as

$$
x_{h}(i)=p_{h}(i)^{-\sigma} P^{\sigma-\frac{1}{1-\gamma}} \quad \text { and } x_{f}(j)=p_{f}(j)^{-\sigma} P^{\sigma-\frac{1}{1-\gamma}}
$$

where $P=\left(\int_{0}^{N_{h}} p_{h}(i)^{1-\sigma} d i+\int_{0}^{N_{f}} p_{f}(j)^{1-\sigma} d j\right)^{\frac{1}{1-\sigma}}$ is the price index. ${ }^{9}$ It can be shown that the representative household's utility can be expressed as

$$
U=I+\frac{1-\gamma}{\gamma} P^{-\frac{\gamma}{1-\gamma}}=W+\Pi+T+\frac{1-\gamma}{\gamma} P^{-\frac{\gamma}{1-\gamma}}
$$

where $W$ is the household's wage income, $\Pi$ is dividend income from firms belonging to the household and $T$ is a lump-sum transfer from the government financed by source-based business taxes.

\section{$2.2 \quad$ Firms}

The numéraire good $y$ is produced by firms in both countries with constant returns to scale technology under perfect competition. Labor productivity in this sector is identical in both countries. The numéraire good $y$ can be freely traded across borders which effectively equalizes wages in both countries.

Upon entering the market, each home firm draws a productivity level, given

\footnotetext{
${ }^{9}$ Note that, due to the quasi-linearity of the utility function, the utility-maximizing quantities do not depend on the income level. Of course, this is different in a world without a numéraire good, which will be discussed in section 3 .
} 
by $1 / a(i)$, where $a(i)$ is the amount of labor the firm $i$ needs to produce a unit of $x(i)$ (cf. Helpman et al., 2004). Firms differ in $a(i)$. For simplicity, assume that $a$ is uniformly distributed over the intervall $\left[a^{-}, a^{+}\right]$and that $a$ increases in the index $i$. Similarly, each foreign firm draws a productivity level $a(j)$. For simplicity, I assume that the distributions of $a(i)$ and $a(j)$ are independent of each other and that $\partial a(i) / \partial i=1$ and $\partial a(j) / \partial j=1$.

In principle, all firms in the differentiated goods sector are allowed to serve both markets. Since both markets are perfectly separated and the paper's focus is on optimal repatriation taxation by the home country government, I will focus on the foreign market in what follows.

Home country firms either export their goods to the foreign market (export regime, denoted by subscript $E$ ) or invest in own production facilities in the foreign country (FDI regime, denoted by subscript $I$ ). In the export regime, the goods are produced in the home country and sold in the foreign country. Production requires a fixed cost of $F_{E}$ units of labor input. Variable costs are the wage rate $w$ (the index of which has been omitted since wage rates are identical in both locations) grossed up by the transport cost $\tau>1$. After-tax profits are then given by

$$
\pi_{E}(i)=\left[(p(i)-a(i) \tau w) x(i)-w F_{E}\right]\left(1-t_{h}\right)
$$

where $t_{h}$ is the corporate tax rate in the home country.

The individual firm chooses $x(i)$ given the choices of all other firms in the economy. It also assumes that its choice has no impact on the price index $P_{f}$. Then, profit-maximizing production choices under the export regime yield a price of

$$
p_{E}(i)=\frac{\sigma}{\sigma-1} a(i) \tau w
$$

If the firm decides to invest in foreign production facilities, production is shifted to the foreign country. However, a fraction $\theta_{I} \in[0,1]$ of production remains at the headquarter (think of management or technology services; Grossman \& Rossi-Hansberg, 2008, use the term "tasks" that can be allocated across locations within the firm). For accounting and tax purposes, the foreign affiliate has to purchase the part of the goods produced in the home country from the home country headquarter at a price of $\delta$. Shifting production abroad may lower the variable pro- 
duction cost, since there is a transport cost related to exporting. However, foreign direct investment involves a higher fixed cost of production, $F_{I}>F_{E}$. After-tax profits are given by

$$
\begin{aligned}
\pi_{I}(i)= & \theta_{I} a(i)(\delta-\tau w) x(i)\left(1-t_{h}\right) \\
& +\left[\left(p(i)-a(i)\left[\left(1-\theta_{I}\right) w+\theta_{I} \delta\right]\right) x(i)-w F_{I}\right]\left(1-t_{e}\right)
\end{aligned}
$$

where $t_{e}$ is the effective tax rate on foreign income equal to $t_{e}=t_{f}+t_{r}\left(1-t_{f}\right)$ and $t_{r}$ is the statutory tax rate on repatriated foreign profits. The profit maximizing price under the FDI regime is given by

$$
p_{I}(i)=\frac{\sigma}{\sigma-1} a(i)\left[\left(1-\theta_{I}\right) w+\theta_{I} \tau w+\theta_{I}(\delta-\tau w) \frac{t_{h}-t_{e}}{1-t_{e}}\right]
$$

If the transfer price exactly reflects the cost of the headquarter input, $\delta=\tau w$, the price $p_{I}$ does not depend on tax rate differentials between $t_{h}$ and $t_{e} \cdot{ }^{10}$ The reason is that, at $\delta=\tau w$, there is no taxable profit at the headquarter location. Since variable costs are deductible at the foreign affiliate and marginal profits are zero, the effective tax on foreign profits, $t_{e}$, does not play a role either. However, if $\delta>\tau w$, part of the foreign profit is shifted to the home country headquarter via intra-firm trade. If the effective tax on headquarter income is higher than on affiliate income, $t_{h}>t_{e}$, this drives up the variable cost and, thus, the profitmaximizing price. Put differently, an increase in the repatriation tax $t_{r}$ reduces the price: $\frac{\partial p_{I}(i)}{\partial t_{r}}=-\frac{\sigma}{\sigma-1} a(i) \theta_{I}(\delta-\tau w) \frac{1-t_{h}}{\left(1-t_{f}\right)\left(1-t_{r}\right)^{2}}$. In the following, I will allow for cases in which $\delta \neq \tau w$ and consider $\delta=\tau w$ as a special case.

Finally, foreign firms have an after-tax profit of

$$
\pi_{f}(j)=\left(1-t_{f}\right)\left[\left(p_{f}(j)-a(j) w\right) x_{f}(j)-w F_{f}\right]
$$

and charge profit maximizing prices of

$$
p_{f}(j)=\frac{\sigma}{\sigma-1} a(j) w
$$

\footnotetext{
${ }^{10}$ Of course, the same is true if $\theta_{I}=0$, i.e. all production takes place at the foreign affiliate and no intra-firm trade occurs.
} 


\subsection{Equilibrium}

The focus of this paper is on the welfare and efficiency properties of repatriation taxation. I therefore take the tax rates $t_{h}$ and $t_{f}$ as given. ${ }^{11}$ Consider the following three decision stages. In the first stage, the home country sets the tax rate $t_{r}$ on repatriated foreign income. In the second stage, all firms choose whether or not to produce and the home country firms choose between the export and the FDI regime. In the third stage, all producing firms and the representative households choose their quantities.

The decisions in the third stage are implicitly determined by equations (7), (9) and (11). The second stage decisions are characterized by three equations which define different margins. At the first two margins, the marginal home and foreign firms make zero profits. Firms with a labor productivity below $1 / a_{f}^{c}$ and $1 / a_{h}^{c}$, respectively, do not have an incentive to enter the market, where $a_{h}^{c}$ and $a_{f}^{c}$ are defined by $\pi_{h}\left(N_{h}\right)=0$ and $\pi_{f}\left(N_{f}\right)=0$ and $N_{h}$ and $N_{f}$ denote the indices of the marginal home country and foreign firms, respectively. At the third margin, the marginal firm is indifferent between exporting and FDI. The threshold level $a_{I}^{c}$ is defined by $\pi_{E}\left(n^{c}\right)=\pi_{I}\left(n^{c}\right)$ where $n^{c}$ is the index of the marginal firm and

$$
\begin{aligned}
& \pi_{E}\left(n^{c}\right)=\left(1-t_{h}\right)\left(\frac{1}{\sigma} p_{E}\left(n^{c}\right)^{1-\sigma} P_{f}^{\sigma-\frac{1}{1-\gamma}}-w F_{E}\right) \\
& \pi_{I}\left(n^{c}\right)=\left(1-t_{e}\right)\left(\frac{1}{\sigma} p_{I}\left(n^{c}\right)^{1-\sigma} P_{f}^{\sigma-\frac{1}{1-\gamma}}-w F_{I}\right)
\end{aligned}
$$

Before I analyze the welfare implications of home country tax policy in the next subsection, it is worth briefly discussing some specific features of the model outlined above. Firstly, only the more productive firms, i.e. firms with a labor productivity above $1 / a_{I}^{c}$ choose the FDI regime if $p_{I}\left(n^{c}\right)<\left(\frac{1-t_{e}}{1-t_{h}}\right)^{\frac{1}{\sigma-1}} p_{E}\left(n^{c}\right)$ which is demonstrated in the appendix. I only consider cases in which this condition

\footnotetext{
${ }^{11}$ This assumption is in line with the standard literature. However, as demonstrated in Devereux (2000), it is of crucial importance. If tax revenue from foreign income can be used to reduce domestic taxes (or increase public goods provision), levying taxes on repatriated dividends may yield efficiency gains. In this setting, the government faces a Ramsey style problem of optimal taxation where optimal tax rates reflect locational elasticities. It should be noted, though, that apart from extreme situations exemption of foreign income is not a likely outcome if domestic taxes are endogenized.
} 
holds. The price level on the foreign market is then given by $P_{f}=\left(\int_{0}^{n^{c}} p_{I}(i)^{1-\sigma} d i\right.$ $\left.+\int_{n^{c}}^{N_{h}} p_{E}(i)^{1-\sigma} d i+\int_{0}^{N_{f}} p_{f}(j)^{1-\sigma} d j\right)^{\frac{1}{1-\sigma}}$. Secondly, FDI increases output as long as $p_{I}(i)<p_{E}(i)$. Thirdly, FDI may cause domestic activity to rise. Here, domestic activity - measured in labor input - does not decline if $\theta_{I} a_{I}^{c} x_{I}\left(n^{c}\right) \geq a_{I}^{c} x_{E}\left(n^{c}\right)+F_{E}$. Note that, without intra-firm trade $\left(\theta_{I}=0\right)$, domestic activity would always decline in response to foreign investment which is why the model part adopted from Grossman \& Rossi-Hansberg (2008) is needed.

All these features are backed by empirical evidence. As indicated in the introduction, some authors presume that this changes the conditions for optimal tax policy substantially. This is to be examined in the next section.

\subsection{Welfare}

In line with the literature, I assume that the home country government maximizes the representative consumer's utility $U_{h}$ which is the sum of wage income, firm profits, tax revenue and consumer surplus in the differentiated goods sector. This implies that the government has two kinds of incentive to levy a tax, i.e. to redistribute funds from the private to the public sector. Firstly, it may want to change the firms' or households' decisions for allocative efficiency reasons. Secondly, it may want to extract rents from foreigners. Since the focus of this paper is on the optimal choice of the repatriation tax levied by the home country which only concerns home country firms, it is possible to abstract from the second incentive to levy taxes by assuming that tax rates $t_{h}$ and $t_{f}$ are given (which is also in line with the literature, see Richman, 1963, and the subsequent contributions cited above). ${ }^{12}$

Due to the quasi-linearity of the utility function, the household's wage income and consumer surplus in the home country are not affected by variations in $t_{r}{ }^{13}$

\footnotetext{
${ }^{12}$ Another option would be to assume that the households have a preference for a publicly provided good. However, such an analysis would also require to endogenize the tax rates $t_{h}$ and $t_{r}$.

${ }^{13}$ Actually, Desai (2009) claims that a tax on foreign profits reduces competition in the home country market ("Overall welfare is reduced at home given the lowered competition amongst firms", p. 11). This may be true if foreign investment lowers variable cost associated with home country production, e.g. due to higher r\&d activity. These effects would require another model, though, and are therefore neglected in the following.
} 
Firm profits can be expressed as

$$
\begin{aligned}
\Pi_{h}= & \left(1-t_{e}\right) \int_{0}^{n^{c}}\left[\frac{1}{\sigma} p_{I}(i)^{1-\sigma} P_{f}^{\sigma-\frac{1}{1-\gamma}}-w F_{I}\right] d i \\
& +\left(1-t_{h}\right) \int_{n^{c}}^{N}\left[\frac{1}{\sigma} p_{E}(i)^{1-\sigma} P_{f}^{\sigma-\frac{1}{1-\gamma}}-w F_{E}\right] d i
\end{aligned}
$$

and tax revenue as

$$
\begin{aligned}
T_{h}= & t_{r}\left(1-t_{f}\right) \int_{0}^{n^{c}}\left[\frac{1}{\sigma} P_{f}^{\sigma-\frac{1}{1-\gamma}} p_{I}(i)^{1-\sigma}-w F_{I}\right] d i \\
& +\theta_{I}\left(\delta-\tau w_{h}\right) \frac{t_{h}-t_{r}}{1-t_{r}} \int_{0}^{n^{c}} a(i) p_{I}(i)^{-\sigma} P_{f}^{\sigma-\frac{1}{1-\gamma}} d i \\
& +t_{h} \int_{n^{c}}^{N}\left[\frac{1}{\sigma} P_{f}^{\sigma-\frac{1}{1-\gamma}} p_{E}(i)^{1-\sigma}-w F_{E}\right] d i
\end{aligned}
$$

To start I assume that the home country government takes the foreign price level as given. This assumption will be relaxed in subsection 2.6. The tax rate on foreign profits, $t_{r}$, is optimally chosen if $\frac{\partial U_{h}}{\partial t_{r}}=0$ with

$$
\begin{aligned}
\frac{\partial U_{h}}{\partial t_{r}}= & -\sigma \theta_{I}\left(\delta-\tau w_{h}\right) \frac{t_{h}-t_{r}}{1-t_{r}} P_{f}^{\sigma-\frac{1}{1-\gamma}} \int_{0}^{n^{c}} a(i) p_{I}(i)^{-\sigma-1} \frac{\partial p_{I}(i)}{\partial t_{r}} d i \\
& +\left[\frac{t_{r}}{1-t_{r}} \pi_{I}\left(n^{c}\right)-\frac{t_{h}}{1-t_{h}} \pi_{E}\left(n^{c}\right)+\theta_{I}\left(\delta-\tau w_{h}\right) \frac{t_{h}-t_{r}}{1-t_{r}} a_{I}^{c} p_{I}\left(n^{c}\right)^{-\sigma} P_{f}^{\sigma-\frac{1}{1-\gamma}}\right] \frac{\partial n^{c}}{\partial t_{r}}
\end{aligned}
$$

which equals zero at $t_{r}=t_{h}$. It can be shown that $\frac{\partial^{2} U_{h}}{\partial t_{r}^{2}}<0 .{ }^{14}$ Thus, the optimal tax system implies full taxation of foreign profits after deducting foreign tax payments. This is the standard results firstly derived by Peggy Musgrave in 1963. The novel result here is that even though the foreign investment generates income and tax revenue in the home country, the home country government has an incentive to fully tax foreign income after deducting foreign tax payments. Note that this is even true if the home country tax revenue of the marginal firm is larger under the FDI regime than under the export regime. Higher domestic tax revenue

\footnotetext{
${ }^{14} \mathrm{~A}$ formal derivation is available upon request.
} 
(at $t_{r}=0$ ) implies that the foreign part of the firm's tax base is negative. ${ }^{15}$ Using $\pi_{E}\left(n^{c}\right)=\pi_{I}\left(n^{c}\right)$, the above equation can be expressed as

$$
\begin{aligned}
\frac{\partial U_{h}}{\partial t_{r}}= & -\sigma \theta_{I}\left(\delta-\tau w_{h}\right) \frac{t_{h}-t_{r}}{1-t_{r}} P_{f}^{\sigma-\frac{1}{1-\gamma}} \int_{0}^{n^{c}} a(i) p_{I}(i)^{-\sigma-1} \frac{\partial p_{I}(i)}{\partial t_{r}} d i \\
& -\frac{t_{h}-t_{r}}{\left(1-t_{r}\right)\left(1-t_{h}\right)}\left[\pi_{I}\left(n^{c}\right)-\left(1-t_{h}\right) \theta_{I}\left(\delta-\tau w_{h}\right) a_{I}^{c} x_{I}\left(n^{c}\right)\right] \frac{\partial n^{c}}{\partial t_{r}}
\end{aligned}
$$

where the term in square brackets is the foreign part of the tax base. If it is negative, the appendix shows that $\frac{\partial n^{c}}{\partial t_{r}}>0$. Thus, at $t_{r}=0, \frac{\partial U_{h}}{\partial t_{r}}>0$.

I can therefore state

Proposition 1 If the home country government does not take into account the effects of its tax policy on the price level, the optimal tax on foreign profits is $t_{r}=t_{h}$ (full taxation after deduction).

What is the intuition behind the above proposition? If, at $t_{r}=0$, tax revenue in the home country are lower if the firm chooses FDI (as in the Musgrave model), the government has an incentive to increase $t_{r}$ to force the marginal firm back into the export regime. In contrast, if tax revenue is larger than under the export regime (as suggested by recent empirical evidence), the government has an incentive to subsidize FDI which can be achieved by increasing $t_{r}$ (recall that the foreign part of the tax base is then negative). Finally, if tax revenues from the marginal firm are equal under both regimes, the foreign part of the tax base is zero. Any tax rate is optimal and increasing $t_{r}$ does not harm the firm or the economy. Thus, in all these cases the government has an incentive to increase $t_{r}$ until $t_{r}=t_{h}$. Then, private and social interests are aligned.

The result in Proposition 1 is diametrically opposed to the views expressed by the exemption proponents. From my point of view, there are two potential sources of misunderstanding, i.e. reasons which have led to the mistaken presumption that exemption is the optimal answer to a situation in which domestic activity by heterogeneous firms increases in response to foreign investment. The first concerns

\footnotetext{
${ }^{15} \mathrm{To}$ be precise, the tax base under the FDI regime is larger if $\theta_{I} a_{I}^{c}(\delta-\tau w) p_{I}\left(n^{c}\right)^{-\sigma} P^{\sigma-\frac{1}{1-\gamma}}>\frac{1}{\sigma} p_{E}\left(n^{c}\right)^{1-\sigma} P^{\sigma-\frac{1}{1-\gamma}}-w F_{E}$. With $\pi_{E}\left(n^{c}\right)=\pi_{I}\left(n^{c}\right)$ it follows that the foreign part of the firm's tax base has to be negative for the above condition to be satisfied.
} 
the investment behaviour by firms. It seems that some of the commentators treat the domestic income increase as an external effect of foreign investment which the firm does not account for in its investment decision. However, as long as there no grave principal-agent issues within the firm, the firm will account for it and invest until the sum of the returns in both locations equals the cost of production. The second source of misunderstanding might be identified in the differentiation of marginal from intra-marginal firms. Seemingly, some commentators have firms in mind which generate positive income abroad and at home. However, such a firm is not at the margin, i.e. will not react to small changes in the tax environment. The model shows that marginal firms have either positive income at home or abroad, but not both.

\subsection{Optimal repatriation taxes when exporting is prohib- itively expensive}

In the model outlined above, the tax on foreign profits mainly affects the margin where firms choose between exporting and FDI. There may be cases, however, in which exporting is no option for servicing the foreign market. For instance, if transport costs are very high, exporting may be prohibitively expensive. In this case, firms either invest in foreign production facilities or do not supply at all. In fact, one might argue that this is the case in which the arguments in favor of exemption (presented in the introduction) actually apply.

In equilibrium, there are two types of firms, home country firms under the FDI regime and foreign firms, which charge prices of (9) and (11), respectively. Furthermore, the equilibrium is characterized by two margins defined by $\pi_{I}\left(n^{c}\right)=$ 0 and $\pi\left(N_{f}\right)=0$.

The sum of firm profits and tax revenue is then given by

$$
\begin{aligned}
\Pi_{h}+T_{h}= & \left(1-t_{f}\right) \int_{0}^{n^{c}}\left[\frac{1}{\sigma} p_{I}(i)^{1-\sigma} P_{f}^{\sigma-\frac{1}{1-\gamma}}-w F_{I}\right] d i \\
& +\theta_{I}\left(\delta-\tau w_{h}\right) \frac{t_{h}-t_{r}}{1-t_{r}} \int_{0}^{n^{c}} a p_{I}(i)^{-\sigma} P_{f}^{\sigma-\frac{1}{1-\gamma}} d i
\end{aligned}
$$

Again, home country wage income and consumer surplus are not affected. The 
effect of a marginal increase in $t_{r}$ on the sum of $\Pi$ and $T$ is given by

$$
\begin{aligned}
\frac{\partial U_{h}}{\partial t_{r}}= & -\sigma \theta_{I}(\delta-\tau w) \frac{t_{h}-t_{r}}{1-t_{r}} P_{f}^{\sigma-\frac{1}{1-\gamma}} \int_{0}^{n^{c}} a(i) p_{I}(i)^{-\sigma-1} \frac{\partial p_{I}(i)}{\partial t_{r}} d i \\
& +t_{r}\left(1-t_{f}\right)\left[\frac{1}{\sigma} p_{I}\left(n^{c}\right)^{1-\sigma} P_{f}^{\sigma-\frac{1}{1-\gamma}}-w F_{I}\right] \frac{\partial n^{c}}{\partial t_{r}} \\
& +\theta_{I}(\delta-\tau w) \frac{t_{h}-t_{r}}{1-t_{r}} a_{I}^{c} p_{I}\left(n^{c}\right)^{-\sigma} P_{f}^{\sigma-\frac{1}{1-\gamma}} \frac{\partial n^{c}}{\partial t_{r}}=0
\end{aligned}
$$

With $\pi_{I}\left(n^{c}\right)=0$, the above expression becomes zero if, again, $t_{r}=t_{h}$. It can be shown that $\frac{\partial^{2} U_{h}}{\partial t_{r}^{2}}<0$. I may thus state

Proposition 2 If exporting is prohibitively expensive and the only way to serve the foreign market is under the FDI regime, the optimal tax system is full taxation after deduction of foreign tax payments $\left(t_{r}=t_{h}\right)$.

What is the intuition behind this result? Since $\pi_{I}\left(n^{c}\right)=0$, a positive home country tax base requires a negative foreign part of the firm's tax base. Therefore, an increase in $t_{r}$ increases FDI. The fiscal cost of subsidizing FDI equals the return, i.e. higher home country tax revenue, if $t_{r}=t_{h}$. If there is no positive tax revenue in the home country, e.g. because $\delta=\tau w$, the tax on foreign income is irrelevant because the foreign tax base is zero as well. A tax rate $t_{r}>0$ reduces the income of the intra-marginal firms, but this has no welfare effect because the firms are owned by the representative household who also receives the tax revenue as a lump-sum transfer.

\subsection{Optimal repatriation taxes when home country taxes affect the foreign price level}

So far I assumed that the home country government neglects that its tax policy affects the consumer price level in the foreign country. However, the government may take into account that an increase in FDI and a resulting drop in the foreign price level deteriorates the profits of other firms supplying in this market. This introduces a strategic aspect into the analysis which has, in the context of the model, two dimensions. Firstly, since an increase in home country firms' quantities 
reduces the market shares of foreign firms, tax policy might be used to extract rents from foreign monopolists, like in Brander \& Spencer (1985) and Eaton \& Grossman (1986). Secondly, accounting for the price level widens the perspective to the aggregate level. As mentioned above, empirical analysis finds that, whereas foreign investment is associated with increased domestic investment within the firm (Desai, Foley \& Hines, 2005), on the aggregate level, an increase in foreign investment crowds out domestic investment nearly dollar for dollar (Feldstein, 1995). Policy-makers might have the incentive to account for this effect on other domestic firms when deciding on tax policy strategies.

How does optimal tax policy look like when the government takes into account price level effects of its tax revenue? The effect of a small increase in $t_{r}$ on the price level in the foreign country is given by

$$
\begin{aligned}
\frac{d P_{f}}{d t_{r}}= & P_{f}^{\sigma} \int_{0}^{n^{c}} p_{I}(i)^{-\sigma} \frac{\partial p_{I}(i)}{\partial t_{r}} d i+\frac{P_{f}^{\sigma}}{1-\sigma}\left(p_{I}\left(n^{c}\right)^{1-\sigma}-p_{E}\left(n^{c}\right)^{1-\sigma}\right) \frac{d n^{c}}{d t_{r}} \\
& +\frac{P_{f}^{\sigma}}{1-\sigma} p_{E}\left(N_{h}\right)^{1-\sigma} \frac{d N_{h}}{d t_{r}}+\frac{P_{f}^{\sigma}}{1-\sigma} p_{f}\left(N_{f}\right)^{1-\sigma} \frac{d N_{f}}{d t_{r}}
\end{aligned}
$$

The first term on the right hand side captures the direct effect of $t_{r}$ on prices $p_{I}(i)$. The second term represents the price level effect of a tax induced change at the export-FDI-margin. The third and fourth terms are the changes at the market entry margin of home and foreign firms, respectively.

The appendix demonstrates that $\frac{d P_{f}}{d t_{r}}$ is ambiguous. This is because two countervailing effects are at work. Given that an increase in $t_{r}$ reduces FDI and $p_{E}\left(n^{c}\right)>p_{I}\left(n^{c}\right)$, this has - ceteris paribus - a positive effect on the price level. However, an increase in $t_{r}$ also reduces the prices of all intra-marginal firms under the FDI regime (as long as $\delta>\tau w$ ). This has - ceteris paribus - a negative effect on the price level. It can be shown that for small $\delta$ approaching the headquarter variable cost $\tau w$, the effect of a tax increase is positive: $\frac{d P_{f}}{d t_{r}}>0$.

Accounting for price level effects of taxation, the first-order condition in (16) 
reads

$$
\begin{aligned}
\frac{\partial U_{h}}{\partial t_{r}}= & -\sigma \theta_{I}\left(\delta-\tau w_{h}\right) \frac{t_{h}-t_{r}}{1-t_{r}} P_{f}^{\sigma-\frac{1}{1-\gamma}} \int_{0}^{n^{c}} a(i) p_{I}(i)^{-\sigma-1} \frac{\partial p_{I}(i)}{\partial t_{r}} d i \\
& +\left[\frac{t_{r}}{1-t_{r}} \pi_{I}\left(n^{c}\right)-\frac{t_{h}}{1-t_{h}} \pi_{E}\left(n^{c}\right)+\theta_{I}\left(\delta-\tau w_{h}\right) \frac{t_{h}-t_{r}}{1-t_{r}} a_{I}^{c} p_{I}\left(n^{c}\right)^{-\sigma} P_{f}^{\sigma-\frac{1}{1-\gamma}}\right] \frac{\partial n^{c}}{\partial t_{r}} \\
& +\frac{\partial(\Pi+T)}{\partial P_{f}} \frac{\partial P_{f}}{\partial t_{r}}
\end{aligned}
$$

With $\frac{\partial(\Pi+T)}{\partial P_{f}}>0$, it follows that, for $t_{r}=t_{h}$, an increase in $t_{r}$ still increases welfare if $\frac{\partial P_{f}}{\partial t_{r}}>0$ and vice versa. I can therefore state

Proposition 3 If an increase in $t_{r}$ increases the price level $P_{f}, \frac{\partial P_{f}}{\partial t_{r}}>0$, the optimal tax rate on foreign profits $t_{r}$ exceeds the tax rate under full taxation after deduction, i.e. $t_{r}>t_{h}$.

What is the intuition behind this effect? An increase in $t_{r}$ reduces the number of firms under the FDI regime. The marginal firm is just indifferent between FDI and exporting. However, all firms profit from an increase in the price level. As a consequence, the sum of firm profits and tax revenue increases. Seen from a different perspective, the tax internalizes an external effect which the firm investing in FDI does not take into account. By having lower variable cost, the price level is reduced which then translates into lower profits for all other firms. Forcing the firm back into exporting thus corrects for this (from a national perspective) inefficiently high level of FDI.

The results for the case in which exporting is prohibitively expensive are similar. An increase in $t_{r}$ reduces all prices and therefore decreases the price level. The effects on the marginal firm are therefore ambiguous: its own profits under FDI are increased for a given price level, but the price level itself is larger and, therefore, profits are - ceteris paribus - lower. An important difference is, though, that if $\delta=\tau w$ the tax rate $t_{r}$ does not affect neither $n^{c}$ nor $P_{f}$. The reason is that $\pi\left(n^{c}\right)=0$ and $\partial p_{I}(i) / \partial t_{r}=0$ in this case. 


\subsection{Global optimality}

By assumption, the nationally optimal tax policy by the home country does not take into account the foreign household's utility $U_{f}$. Again, it is worthwhile to recall that, in the Musgrave model, the nationally optimal tax policy (full taxation after deduction) implies inefficiently high tax rates from a global point of view. The reason is that the home government considers foreign taxes as costs although, from a global viewpoint, taxes are just funds redistributed from the private to the public sector. What are the efficiency features of nationally optimal tax policy in our model?

Global welfare is simply the sum of home country and foreign welfare. The latter is given by $U_{f}=W_{f}+\Pi_{f}+T_{f}+\frac{1-\gamma}{\gamma} P_{f}^{-\frac{\gamma}{1-\gamma}}$ where $\frac{1-\gamma}{\gamma} P_{f}^{-\frac{\gamma}{1-\gamma}}$ is consumer surplus. Foreign profits $\Pi_{f}$ are given by

$$
\Pi_{f}=\left(1-t_{f}\right) \int_{0}^{N_{f}}\left[\frac{1}{\sigma} p_{f}(j)^{1-\sigma} P_{f}^{\sigma-\frac{1}{1-\gamma}}-w F_{f}\right] d j
$$

and foreign tax revenue by

$$
\begin{aligned}
T_{f}= & t_{f} \int_{0}^{n^{c}}\left(\frac{1}{\sigma} P_{f}^{\sigma-\frac{1}{1-\gamma}} p(i)^{1-\sigma}-w F_{I}\right) d i+t_{f} \int_{0}^{N_{f}}\left(\frac{1}{\sigma} P_{f}^{\sigma-\frac{1}{1-\gamma}} p_{f}(j)^{1-\sigma}-w F_{f}\right) d j \\
& -\theta_{I}\left(\delta-\tau w_{h}\right) t_{f} \frac{1-t_{h}}{1-t_{e}} P_{f}^{\sigma-\frac{1}{1-\gamma}} \int_{0}^{n^{c}} a(i) p_{I}(i)^{-\sigma} d i
\end{aligned}
$$

The question arises how $t_{r}$ affects the foreign household's utility. Global welfare $W_{g}$ can be expressed as

$$
\begin{aligned}
W_{g}= & \left(\frac{1}{\sigma}+\frac{1-\gamma}{\gamma}\right) P_{f}^{-\frac{\gamma}{1-\gamma}}-\int_{0}^{n^{c}} w F_{I} d i-\int_{n^{c}}^{N_{h}} w F_{E} d i-\int_{0}^{N_{f}} w F_{f} d j \\
& +\theta_{I}\left(\delta-\tau w_{h}\right)\left(\frac{t_{h}-t_{e}}{1-t_{e}}\right) \int_{0}^{n^{c}} a(i) p_{I}(i)^{-\sigma} P_{f}^{\sigma-\frac{1}{1-\gamma}} d i
\end{aligned}
$$

I can state

Proposition 4 If $\frac{\partial P_{f}}{\partial t_{r}}>0$, a reduction of $t_{r}$ starting from $t_{r}=t_{h}$ unambiguously increases global welfare. The optimal tax system implies $t_{e}<t_{h}$.

Proof. See appendix. 
The intuition behind this proposition is the following. An increase in $t_{r}$ if optimally chosen by the home country government does not affect home country welfare. From the viewpoint of the foreign country, it increases the price level, reduces the number of home country firms in the foreign country and increases entry of foreign firms into the market. It can be shown that, firstly, an increasing price level reduces consumer surplus more than it increases firm profits and tax revenue and, secondly, that the loss in welfare due to a reduction of home country firms' FDI dominates the welfare gain due to increased market entry.

The above proposition has three important implications. Firstly, the tax credit system is not a globally optimal tax policy choice. Secondly, it cannot be excluded that the exemption system is globally optimal. At $t_{e}=t_{h}$, (credit system), it is still desirable to reduce the tax in order to increase consumer surplus. Thirdly, since the tax credit system replicates the allocation, prices and quantities in the absence of taxes, the above proposition implies that a globally optimal tax system with $t_{e}<t_{h}$ attains a higher global welfare level than in the absence of taxation. The reason is that the market is characterized by imperfect competition. There is too little FDI in the absence of taxation since firms do not account for the resulting decrease in consumer prices.

\section{Extensions and discussion}

In this section, I discuss some crucial issues related to the model presented above and compare the model results to those in the standard literature. Crucial modelling issues concern the transfer price $\delta(3.1)$, implications for the labor market (3.2) and modelling choices with respect to taxation (3.3). Linkages to the existing literature are discussed in section 3.4.

The choice of the transfer price $\delta$ : So far, the transfer price $\delta$ has been treated as an exogenous variable. This may be questioned for two reasons. Firstly, it is often assumed in the literature that firms have some discretion in manipulating transfer prices for tax saving purposes. Firms would have an incentive to charge the lowest possible transfer prices as long as $t_{e}<t_{h}$. A natural lower bound of transfer prices might be the variable headquarter cost $\tau w_{h}$. However, at $t_{e}>t_{h}$, 
this behaviour is reversed. While endogenizing the transfer price is clearly beyond the scope of this paper, it should be noted that the results do not crucially depend on the actual level of $\delta$. Secondly, in bilateral tax agreements, national governments often agree on some system of transfer price rules that effectively split the tax base according to some notion of fairness. It is an interesting question how transfer pricing rules can be used to align the incentives for the two national governments involved given the investment behaviour of multinational firms. This is, however, beyond the scope of this paper.

Labor market effects: In the model presented above, it is possible to abstract from labor market effects of tax policy choices due to the assumptions of a quasilinear utility function and the existence of a numéraire good. Assuming quasilinearity of the utility function greatly simplifies the analysis but, of course, also restricts the model results in their generality. Without a numéraire good which enters linearly into the utility function, wages would adjust to tax rate changes. Similarly, the labor market would play an important role if labor was not mobile across the $x$ and the $y$ sector, if unions increase the wage in the $x$ sector or if labor is taxed differently across sectors. While the precise welfare effects of labor market adjustments due to taxation crucially depends on how the labor market and its frictions are modelled, it is nevertheless possible to give an intuition what the effects look like.

Consider therefore the tax effects on labor demand in the home country. Let $L_{X h}$ denote the labor input in the differentiated goods sector in the home country given by

$$
L_{X h}=\int_{0}^{n^{c}} \theta_{I} x_{I}(i) d i+\int_{n^{c}}^{N_{h}} x_{E}(i) d i
$$

A small increase in $t_{r}$ has the following effect on labor input

$$
\frac{\partial L_{X h}}{\partial t_{r}}=\int_{0}^{n^{c}} \theta_{I} \frac{\partial x_{I}(i)}{\partial t_{r}} d i+\int_{n^{c}}^{N} \frac{\partial x_{E}(i)}{\partial t_{r}} d i+\left(\theta_{I} x_{I}\left(n^{c}\right)-x_{E}\left(n^{c}\right)\right) \frac{\partial n^{c}}{\partial t_{r}}+x_{E}\left(N_{h}\right) \frac{\partial N_{h}}{\partial t_{r}}
$$

It follows from (4) and $x_{E}\left(N_{h}\right)=0$ that $\frac{\partial x_{I}(i)}{\partial t_{r}}, \frac{\partial x_{E}(i)}{\partial t_{r}}, \frac{\partial N_{h}}{\partial t_{r}}$ depend on $\frac{\partial P_{f}}{\partial t_{r}} \lessgtr 0$. Furthermore, it is a priori possible that the marginal firm extends its home country activity in response to foreign investment: $\theta_{I} x_{I}\left(n^{c}\right)>x_{E}\left(n^{c}\right)$. Thus, the overall 
effect of an increase in $t_{r}$ on labor demand is ambiguous. Endogenous wages might therefore serve as an argument in favor of and against levying positive taxes on foreign profits. However, it seems that the arguments against taxing foreign income are not based on subtle general equilibrium wage effects which suggests sticking to the simpler model version with a numéraire good.

Modelling taxes: A third issue worth discussing is the choice of how to model taxes in a trade model with heterogeneous firms and monopolistic competition and the question of deductibility. In line with the literature on heterogeneous multinational firms, see e.g. Melitz (2003), I assumed that variable costs are labor costs and thus deductible. With certain transfer prices, $\delta=\tau w$, corporate taxes do not distort the profit-maximizing quantity choices. They only distort the choice between the export and the FDI regime. This would be different, if it was assumed that (part of) the variable cost is capital expenditures. Then, an increase in the repatriation tax $t_{r}$ would - ceteris paribus - increase the variable cost of all intramarginal firms which would give rise to new complexities. For instance, market entry of marginal exporting firms would have a positive welfare effect.

It is therefore important to note that the above derived results refers to repatriation taxes on foreign profits and not on foreign production inputs. I leave the integration of input taxes and the resulting complexities to further research.

Links to the literature: The results derived above show that some of the classical results in the tradition of Peggy Musgrave remain robust against the introduction of firm heterogeneity, imperfect competition and intra-firm trade. They are not a trivial replication of the standard theory, though. It is worth discussing what the framework presented here has in common with the classical one and where are the crucial differences.

The most important difference concerns the question how domestic and foreign activity are related. In the Musgrave framework, savings are distributed across locations. A dollar invested abroad cannot be invested at home - investment projects in both locations are therefore substitutes. In contrast, in the above presented framework an increase in activity abroad (FDI) does not necessarily reduce activity at home. One of the main insights of this paper is, that the 
desirability of taxing foreign income does not depend on the effects of foreign activity on domestic activity (e.g. measured by tax revenue).

Moreover, capital productivity in the Musgrave framework entirely depends on the location. A dollar of additional investment reduces the marginal productivity of capital in a given location and vice versa. In the framework presented here productivity is firm-specific. Furthermore, the Musgrave model assumes homogeneous firms whereas the framework considered here explicitly allows for firm heterogenity. This allows determining endogenously which firms produce, which ones export and which ones invest in foreign production facilities. Finally, this paper explicitly allows for imperfect competition. This difference to the classical framework is important because a tax on foreign profits is sometimes interpreted in the context of strategic trade policy since, under imperfect competition, national firms may extract rents from foreign markets and thus hurt their competitors. ${ }^{16}$ As this paper demonstrates, a tax on foreign profits is nevertheless optimal. Imperfect competition is also the reason that the global optimality of the tax credit system does not hold anymore. As it is shown above, proponents of the exemption system should argue more with the notion of global optimality than with the national interest.

\section{Conclusion}

One of the recently promoted arguments in favor of the exemption system goes as follows: If foreign investment does not affect or even fosters domestic activity, taxing foreign income is no longer desirable. In this paper, I build a model with heterogeneous firms and intra-firm trade and derive the choice of the optimal tax rate on foreign profits. It turns out that, even though foreign investment may be associated with increased domestic investment and higher domestic tax revenues, the optimal tax system implies full taxation of foreign income after deducting foreign tax payments. Thus, exemption is not an optimal choice from the national point of view. The standard view on foreign profit taxation prevails. However, the globally optimal tax rate is lower than the one chosen under a tax credit system (which has been considered globally optimal in the standard model). This may

\footnotetext{
${ }^{16}$ In the context of monopolistic competition, negative external effects of increasing quantities on other firms' profit levels occur because the price level is affected.
} 
imply, under certain circumstances, that exemption is optimal from a global point of view.

Of course, the model results should be seen in the light of the many restrictions due to the specificity of the model assumption. As the literature cited in the introduction shows, a change in assumption is likely to translate into a change in the recommendation for optimal tax policy. In fact, policy-makers are aware of this conditionality; for instance, a US Treasury report states that "[n]one of the proposed standards [of international taxation] fits all cases and tax policy cannot feasibly be calibrated to have different rules for different cases" (United States Department of the Treasury, Office of Tax Policy, 2007). ${ }^{17}$ It should therefore be recalled that the purpose of this paper is to analyze specific arguments based on the empirical finding that foreign investment need not be associated with reduced domestic activity. The paper's aim is to check whether tax exemption is an optimal tax policy response in this economic environment. It turns out that in such a situation exempting foreign income from tax is not an optimal strategy although there may be other good arguments in favor of doing so.

\section{References}

[1] Becker, J. \& Fuest, C. (forthcoming). Taxing Foreign Profits with International Mergers and Acquisitions, International Economic Review.

[2] Bond, E. W. \& Samuelson, L. (1989). Strategic Behavior and the Rules for International Taxation of Capital, Economic Journal 99(398): 1099-1111.

[3] Bucovetsky, S. \& Wilson, J. (1991). Tax Competition with Two Tax Instruments, Regional Science and Urban Economics 21(3): 333-350.

[4] Chor, D. (2009). Subsidies for FDI: Implications from a Model with Heterogeneous Firms, Journal of International Economics 78(1): 113-25.

\footnotetext{
${ }^{17}$ Devereux (2008) takes this finding as an argument in favor of exempting foreign income from tax: "If governments cannot design tax systems which vary according to firm or sector characteristics, but are forced to implement general tax structures, then (...) the underlying presumption should be in favour of a system which does not tax foreign income of domestic corporations." (p. 711)
} 
[5] Davies, R. B. (2003). The OECD Model Tax Treaty: Tax Competition and Two-Way Capital Flows, International Economic Review 44(2): 113-39.

[6] Desai, M. A. (2009). Securing Jobs or the New Protectionism?: Taxing the Overseas Activities of Multinational Firms, Harvard Business School Finance Working Paper No. 09-107.

[7] Desai, M. A., Foley, C. F. \& Hines, J. R. (2009). Domestic Effects of the Foreign Activities of U.S. Multinationals, American Economic Journal: Economic Policy 1(1): 181-203.

[8] Desai, M. A. and Hines, J. R. (2003). Evaluating International Tax Reform, National Tax Journal 56(3): 487-502.

[9] Desai, M. A. and Hines, J. R. (2004). Old Rules and New Realities: Corporate Tax Policy in a Global Setting, National Tax Journal 57(4): 937-60.

[10] Devereux, M. P. (2000). Some Optimal Tax Rules for International Portfolio and Direct Investment, Finanzarchiv 60(1): 1-23.

[11] Devereux, M. P. (2007). The Impact of Taxation on the Location of Capital, Firms and Profit: A Survey of Empirical Evidence, Oxford University Centre for Business Taxation Working Paper Series No. 07/2.

[12] Devereux, M. P. (2008). Taxation of Outbound Direct Investment: Economic Principles and Tax Policy Considerations, Oxford Review of Economic Policy 24(4): 698-719.

[13] Devereux, M. P. \& Hubbard, R. G. (2003). Taxing Multinationals, International Tax and Public Finance 10(4): 469-87.

[14] Dharmapala, D.; Foley, C. F. \& Forbes, K. J. (2009). Watch what I Do, not what I Say: The Unintended Consequences of the Homeland Investment Act, NBER Working Paper No. 15023.

[15] Eaton, J. \& Grossman, G. M. (1986). Optimal Trade and Industrial Policy under Oligopoly, Quarterly Journal of Economics 101(2): 383-406. 
[16] Egger, P. \& Pfaffermayr, M. (2003). The Counterfactual to Investing Abroad: An Endogenous Treatment Approach of Foreign Affiliate Activity, University of Innsbruck Working Papers in Economics No. 2003-2.

[17] Feldstein, M. \& Hartman, D. (1979). The Optimal Taxation of Foreign Source Investment Income, Quarterly Journal of Economics 93(4): 613-629.

[18] Grubert, H. \& Mutti, J. (1995). Taxing Multinationals in a World with Portfolio Flows and R\&D - Is Capital Export Neutrality Obsolete?, International Tax and Public Finance 2(3): 439-457.

[19] Hamada, K. (1966). Strategic Aspects of Taxation on Foreign Investment Income, Quarterly Journal of Economics 80(3): 361-375.

[20] Helpman, E.; Melitz, M. J. and Yeaple, S. R. (2004). Export Versus FDI with Heterogenous Firms, American Economic Review 94(1): 300-316.

[21] HM Treasury and HM Revenue and Customs (2007). Taxation of Companies' Foreign Profits: Discussion Document.

[22] Hines, J. R. (2008). Foreign Income and Domestic Deductions, National Tax Journal 61(3): 461-75.

[23] Horst, T. (1980). A Note on the Optimal Taxation of International Investment Income, Quarterly Journal of Economics 94(4): 793-798.

[24] Janeba, E. (1995). Corporate Income Tax Competition, Double Taxation Treaties, and Foreign Direct Investment, Journal of Public Economics 56(2): $311-326$.

[25] Keen, M. \& Piekkola, H. (1997). Simple Rules for the Optimal Taxation of International Capital Income, Scandinavian Journal of Economics 99(3): 447461.

[26] Kleinert, J. \& Toubal, F. (forthcoming). The Impact of Locating Production Abroad on Activities at Home: Evidence from German Firm-Level Data. Review of World Economics. 
[27] Mintz, J. \& Tulkens, H. (1996). Optimality Properties of Alternative Systems of Taxation of Foreign Capital Income, Journal of Public Economics 60(3): 373-399.

[28] Melitz, M. J. (2003). The Impact of Trade on Intra-Industry Reallocations and Aggregate Industry Productivity, Econometrica 71(6): 1695-1725.

[29] Musgrave, P. B. (1969). United States Taxation of Foreign Investment Income: Issues and Arguments, Cambridge (MA), International Tax Program, Harvard Law School.

[30] Richman, P. B. (1963). Taxation of Foreign Investment Income - An Economic Analysis, The Johns Hopkins Press, Baltimore.

[31] Simpson, H. (2008). Investment Abroad and Adjustment at Home: Evidence from UK Multinational Firms, CMPO working paper 08/207.

[32] Voget (2009). Impact of Taxation on the Location of Corporate Headquarters, mimeo.

[33] United States Department of the Treasury, Office of Tax Policy (2007). Approaches to Improve the Competitiveness of the US Business Tax System for the 21st Century.

\section{Appendix}

\section{Appendix 1: Productive firms choose FDI}

This appendix derives the conditions under which the more productive firms choose the FDI regime and the less productive firms prefer exporting. A firm is indifferent between exporting and FDI at $\pi_{E}\left(n^{c}\right)-\pi_{I}\left(n^{c}\right)=0$. With $\frac{\partial p_{E}(i)}{\partial a(i)}=\frac{p_{E}(i)}{a(i)}$ and $\frac{\partial p_{I}(i)}{\partial a(i)}=\frac{p_{I}(i)}{a(i)}$, an increase in $n^{c}$ has the following impact

$\frac{\partial\left[\pi_{E}\left(n^{c}\right)-\pi_{I}\left(n^{c}\right)\right]}{\partial n^{c}}=\frac{\sigma-1}{\sigma} P_{f}^{\sigma-\frac{1}{1-\gamma}} \frac{1}{a_{I}^{c}}\left[\left(1-t_{e}\right) p_{I}\left(n^{c}\right)^{1-\sigma}-\left(1-t_{h}\right) p_{E}\left(n^{c}\right)^{1-\sigma}\right]$ 
It follows that the above expression is positive, i.e. the more productive firms choose FDI, if

$$
p_{I}\left(n^{c}\right)<\left(\frac{1-t_{h}}{1-t_{e}}\right)^{\frac{1}{1-\sigma}} p_{E}\left(n^{c}\right)
$$

What is the effect of a small increase in $t_{r}$ on the export-FDI-margin, i.e. on $n^{c}$ ? Differentiating $\pi_{E}\left(n^{c}\right)-\pi_{I}\left(n^{c}\right)=0$ with respect to $n^{c}$ and $t_{r}$, gives $d n^{c} / d t_{r}=-\frac{\partial\left[\pi_{E}\left(n^{c}\right)-\pi_{I}\left(n^{c}\right)\right]}{\partial t_{r}} / \frac{\partial\left[\pi_{E}\left(n^{c}\right)-\pi_{I}\left(n^{c}\right)\right]}{\partial n^{c}}$ where $\frac{\partial\left[\pi_{E}\left(n^{c}\right)-\pi_{I}\left(n^{c}\right)\right]}{\partial n^{c}}>0$ is derived above. $\frac{\partial\left[\pi_{E}\left(n^{c}\right)-\pi_{I}\left(n^{c}\right)\right]}{\partial\left(1-t_{r}\right)}$ is given by

$$
\frac{\partial\left[\pi_{E}\left(n^{c}\right)-\pi_{I}\left(n^{c}\right)\right]}{\partial t_{r}}=\frac{\pi_{I}\left(n^{c}\right)}{1-t_{r}}+\left(1-t_{e}\right) \frac{\sigma-1}{\sigma} P_{f}^{\sigma-\frac{1}{1-\gamma}} p_{I}\left(n^{c}\right)^{-\sigma} \frac{\partial p_{I}(i)}{\partial t_{r}}
$$

It follows that $\frac{d n^{c}}{d t_{r}}=-\frac{\partial\left[\pi_{E}\left(n^{c}\right)-\pi_{I}\left(n^{c}\right)\right]}{\partial t_{r}} / \frac{\partial\left[\pi_{E}\left(n^{c}\right)-\pi_{I}\left(n^{c}\right)\right]}{\partial n^{c}}$ is negative if $\frac{\partial\left[\pi_{E}\left(n^{c}\right)-\pi_{I}\left(n^{c}\right)\right]}{\partial t_{r}}>$ 0 which is the case if

$$
\begin{aligned}
\frac{\partial\left[\pi_{E}\left(n^{c}\right)-\pi_{I}\left(n^{c}\right)\right]}{\partial t_{r}}= & \left(1-t_{f}\right)\left[\frac{1}{\sigma} P_{f}^{\sigma-\frac{1}{1-\gamma}} p_{I}\left(n^{c}\right)^{1-\sigma}-w F_{I}\right] \\
& -a_{I}^{c} \theta_{I}(\delta-\tau w) \frac{1-t_{h}}{1-t_{r}} P_{f}^{\sigma-\frac{1}{1-\gamma}} p_{I}\left(n^{c}\right)^{-\sigma}
\end{aligned}
$$

This equation can be expressed as

$$
\frac{\partial\left[\pi_{E}\left(n^{c}\right)-\pi_{I}\left(n^{c}\right)\right]}{\partial t_{r}}=\left[\left(p\left(n^{c}\right)-a_{I}^{c}\left[\left(1-\theta_{I}\right) w+\theta_{I} \delta\right]\right) x\left(n^{c}\right)-w F_{I}\right]\left(1-t_{f}\right)
$$

It follows that $\frac{\partial\left[\pi_{E}\left(n^{c}\right)-\pi_{I}\left(n^{c}\right)\right]}{\partial t_{r}}>0$ as long as the foreign part of the firm's tax base is positive.

\section{Appendix 2: Accounting for changes in the price level}

In this appendix, I derive the effect of a small increase in $t_{r}$ on the endogenous variables that characterize the equilibrium accounting for effects on the foreign price level $P_{f}$. The export-FDI-margin is characterized by $\pi_{E}\left(n^{c}\right)=\pi_{I}\left(n^{c}\right)$, the entry margin for home country firms by $\pi_{E}\left(N_{h}\right)=0$, the entry margin for foreign 
firms by $\pi_{f}\left(N_{f}\right)=0$ and the price level is given by

$$
P_{f}=\left(\int_{0}^{n^{c}} p_{I}(i)^{1-\sigma} d i+\int_{n^{c}}^{N_{h}} p_{E}(i)^{1-\sigma} d i+\int_{0}^{N_{f}} p_{f}(j)^{1-\sigma} d j\right)^{\frac{1}{1-\sigma}}
$$

These four equations define the endogenous variables $n^{c}, N_{h}, N_{f}$ and $P_{f}$. The total differential is given by

$$
\begin{aligned}
n^{c}: & \quad \frac{\partial\left(\pi_{E}\left(n^{c}\right)-\pi_{I}\left(n^{c}\right)\right)}{\partial P_{f}} d P_{f}+\frac{\partial\left(\pi_{E}\left(n^{c}\right)-\pi_{I}\left(n^{c}\right)\right)}{\partial n^{c}} d n^{c}+\frac{\partial\left(\pi_{E}\left(n^{c}\right)-\pi_{I}\left(n^{c}\right)\right)}{\partial t_{r}} d t_{r}=0 \\
N_{h}: & \quad \frac{\partial \pi_{E}\left(N_{h}\right)}{\partial N_{h}} d N_{h}+\frac{\partial \pi_{E}\left(N_{h}\right)}{\partial P_{f}} d P_{f}=0 \\
N_{f}: \quad & \quad \frac{\partial \pi_{f}\left(N_{f}\right)}{\partial N_{f}} d N_{f}+\frac{\partial \pi_{f}\left(N_{f}\right)}{\partial P_{f}} d P_{f}=0 \\
P_{f}: \quad & d P_{f}=\frac{P_{f}^{\sigma}}{1-\sigma}\left(p_{I}\left(n^{c}\right)^{1-\sigma}-p_{E}\left(n^{c}\right)^{1-\sigma}\right) d n^{c}+\frac{P_{f}^{\sigma}}{1-\sigma} p_{E}\left(N_{h}\right)^{1-\sigma} d N_{h} \\
& +\frac{P_{f}^{\sigma}}{1-\sigma} p_{f}\left(N_{f}\right)^{1-\sigma} d N_{f}+\left(P_{f}^{\sigma} \int_{0}^{n^{c}} p_{I}(i)^{-\sigma} \frac{\partial p_{I}(i)}{\partial t_{r}} d i\right) d t_{r}
\end{aligned}
$$

Solving for $d n^{c}$ and $d t_{r}$ yields

$$
\frac{d n^{c}}{d t_{r}}=-\frac{\frac{\partial\left(\pi_{E}\left(n^{c}\right)-\pi_{I}\left(n^{c}\right)\right)}{\partial t_{r}}+\frac{\frac{\partial\left(\pi_{E}\left(n^{c}\right)-\pi_{I}\left(n^{c}\right)\right)}{\partial P_{f}} \frac{\partial \pi_{f}\left(N_{f}\right)}{\partial N_{f}} \frac{\partial \pi_{E}\left(N_{h}\right)}{\partial N_{h}} P_{f}^{\sigma} \int_{0}^{n^{c}} p_{I}(i)^{-\sigma} \frac{\partial p_{I}(i)}{\partial t_{r}} d i}{\frac{\partial \pi_{E}\left(N_{h}\right)}{\partial N_{h}}\left(\frac{\partial \pi_{f}\left(N_{f}\right)}{\partial N_{f}}+\frac{\partial \pi_{f}\left(N_{f}\right)}{\partial P_{f}} \frac{P_{f}^{\sigma}}{1-\sigma} p_{f}\left(N_{f}\right)^{1-\sigma}\right)+\frac{P_{f}^{\sigma}}{1-\sigma} p_{E}\left(N_{h}\right)^{1-\sigma} \frac{\partial \pi_{E}\left(N_{h}\right)}{\partial P_{f}} \frac{\partial \pi_{f}\left(N_{f}\right)}{\partial N_{f}}}}{\frac{\partial\left(\pi_{E}\left(n^{c}\right)-\pi_{I}\left(n^{c}\right)\right)}{\partial n^{c}}+\frac{\frac{\partial\left(\pi_{E}\left(n^{c}\right)-\pi_{I}\left(n^{c}\right)\right)}{\partial P_{f}} \frac{P_{f}^{\sigma}}{1-\sigma}\left(p_{I}\left(n^{c}\right)^{1-\sigma}-p_{E}\left(n^{c}\right)^{1-\sigma}\right) \frac{\partial \pi_{f}\left(N_{f}\right)}{\partial N_{f}} \frac{\partial \pi_{E}\left(N_{h}\right)}{\partial N_{h}}}{\frac{\partial \pi_{E}\left(N_{h}\right)}{\partial N_{h}}\left(\frac{\partial \pi_{f}\left(N_{f}\right)}{\partial N_{f}}+\frac{\partial \pi_{f}\left(N_{f}\right)}{\partial P_{f}} \frac{P_{f}^{\sigma}}{1-\sigma} p_{f}\left(N_{f}\right)^{1-\sigma}\right)+\frac{P_{f}^{\sigma}}{1-\sigma} p_{E}\left(N_{h}\right)^{1-\sigma} \frac{\partial \pi_{E}\left(N_{h}\right)}{\left.\partial P_{f}\right)} \frac{\partial \pi_{f}\left(N_{f}\right)}{\partial N_{f}}}}
$$

Solving for $d N_{h}$ yields

$$
\begin{aligned}
\frac{d N_{h}}{d t_{r}}= & -\frac{\frac{\partial \pi_{E}\left(N_{h}\right)}{\partial P_{f}} \frac{P_{f}^{\sigma}}{1-\sigma}\left(p_{I}\left(n^{c}\right)^{1-\sigma}-p_{E}\left(n^{c}\right)^{1-\sigma}\right) \frac{\partial \pi_{f}\left(N_{f}\right)}{\partial N_{f}}}{\frac{\partial \pi_{E}\left(N_{h}\right)}{\partial N_{h}}\left(\frac{\partial \pi_{f}\left(N_{f}\right)}{\partial N_{f}}+\frac{\partial \pi_{f}\left(N_{f}\right)}{\partial P_{f}} \frac{P_{f}^{\sigma}}{1-\sigma} p_{f}\left(N_{f}\right)^{1-\sigma}\right)+\frac{P_{f}^{\sigma}}{1-\sigma} p_{E}\left(N_{h}\right)^{1-\sigma} \frac{\partial \pi_{E}\left(N_{h}\right)}{\partial P} \frac{\partial \pi_{f}\left(N_{f}\right)}{\partial N_{f}}} \frac{d n^{c}}{d t_{r}} \\
& -\frac{\frac{\partial \pi_{E}\left(N_{h}\right)}{\partial P} \frac{\partial \pi_{f}\left(N_{f}\right)}{\partial N_{f}} P^{\sigma} \int_{0}^{n^{c}} p_{I}(i)^{-\sigma} \frac{\partial p_{I}(i)}{\partial t_{r}} d i}{\frac{\partial \pi_{E}\left(N_{h}\right)}{\partial N_{h}}\left(\frac{\partial \pi_{f}\left(N_{f}\right)}{\partial N_{f}}+\frac{\partial \pi_{f}\left(N_{f}\right)}{\partial P_{f}} \frac{P_{f}^{\sigma}}{1-\sigma} p_{f}\left(N_{f}\right)^{1-\sigma}\right)+\frac{P_{f}^{\sigma}}{1-\sigma} p_{E}\left(N_{h}\right)^{1-\sigma} \frac{\partial \pi_{E}\left(N_{h}\right)}{\partial P_{f}} \frac{\partial \pi_{f}\left(N_{f}\right)}{\partial N_{f}}}
\end{aligned}
$$


Solve for $d N_{f}$ :

$$
\begin{aligned}
\frac{d N_{f}}{d t_{r}}= & -\frac{\frac{\partial \pi_{f}\left(N_{f}\right)}{\partial P_{f}} \frac{P_{f}^{\sigma}}{1-\sigma}\left(p_{I}\left(n^{c}\right)^{1-\sigma}-p_{E}\left(n^{c}\right)^{1-\sigma}\right) \frac{\partial \pi_{E}\left(N_{h}\right)}{\partial N_{h}}}{\frac{\partial \pi_{E}\left(N_{h}\right)}{\partial N_{h}}\left(\frac{\partial \pi_{f}\left(N_{f}\right)}{\partial N_{f}}+\frac{\partial \pi_{f}\left(N_{f}\right)}{\partial P_{f}} \frac{P_{f}^{\sigma}}{1-\sigma} p_{f}\left(N_{f}\right)^{1-\sigma}\right)+\frac{P_{f}^{\sigma}}{1-\sigma} p_{E}\left(N_{h}\right)^{1-\sigma} \frac{\partial \pi_{E}\left(N_{h}\right)}{\partial P_{f}} \frac{\partial \pi_{f}\left(N_{f}\right)}{\partial N_{f}}} \frac{d n^{c}}{d t_{r}} \\
& -\frac{\frac{\partial \pi_{E}\left(N_{h}\right)}{\partial N_{h}} \frac{\partial \pi_{f}\left(N_{f}\right)}{\partial P_{f}} P_{f}^{\sigma} \int_{0}^{n^{c}} p_{I}(i)^{-\sigma} \frac{\partial p_{I}(i)}{\partial t_{r}} d i}{\frac{\partial \pi_{E}\left(N_{h}\right)}{\partial N_{h}}\left(\frac{\partial \pi_{f}\left(N_{f}\right)}{\partial N_{f}}+\frac{\partial \pi_{f}\left(N_{f}\right)}{\partial P_{f}} \frac{P_{f}^{\sigma}}{1-\sigma} p_{f}\left(N_{f}\right)^{1-\sigma}\right)+\frac{P_{f}^{\sigma}}{1-\sigma} p_{E}\left(N_{h}\right)^{1-\sigma} \frac{\partial \pi_{E}\left(N_{h}\right)}{\partial P_{f}} \frac{\partial \pi_{f}\left(N_{f}\right)}{\partial N_{f}}}
\end{aligned}
$$

It can be shown that, if $\delta=w_{h}, \frac{d n^{c}}{d t_{r}}<0$ and $\frac{d N_{h}}{d t_{r}}, \frac{d N_{f}}{d t_{r}}>0$.

Now, the change in the price level can be calculated. Replacing $\frac{d n^{c}}{d t_{r}}, \frac{d N_{h}}{d t_{r}}$ and $\frac{d N_{f}}{d t_{r}}$ in the total differential expression given above this expression reads

$\frac{d P_{f}}{d t_{r}}=\frac{\left(\frac{P_{f}^{\sigma}}{1-\sigma}\left(p_{I}\left(n^{c}\right)^{1-\sigma}-p_{E}\left(n^{c}\right)^{1-\sigma}\right) \frac{d n^{c}}{d t_{r}}+P_{f}^{\sigma} \int_{0}^{n^{c}} p_{I}(i)^{-\sigma} \frac{\partial p_{I}(i)}{\partial t_{r}} d i\right) \frac{\partial \pi_{E}\left(N_{h}\right)}{\partial N_{h}} \frac{\partial \pi_{f}\left(N_{f}\right)}{\partial N_{f}}}{\frac{\partial \pi_{E}\left(N_{h}\right)}{\partial N_{h}}\left(\frac{\partial \pi_{f}\left(N_{f}\right)}{\partial N_{f}}+\frac{\partial \pi_{f}\left(N_{f}\right)}{\partial P_{f}} \frac{P_{f}^{\sigma}}{1-\sigma} p_{f}\left(N_{f}\right)^{1-\sigma}\right)+\frac{P_{f}^{\sigma}}{1-\sigma} p_{E}\left(N_{h}\right)^{1-\sigma} \frac{\partial \pi_{E}\left(N_{h}\right)}{\partial P} \frac{\partial \pi_{f}\left(N_{f}\right)}{\partial N_{f}}}$

\section{Appendix 3: Global optimality}

In this appendix, I derive the first-order condition of $t_{r}$ for global welfare. Adding home country profits in (14), home country tax revenue in (15), foreign profits in (22), foreign tax revenue in (23), and foreign consumer surplus given by $\frac{1-\gamma}{\gamma} P_{f}^{-\frac{\gamma}{1-\gamma}}$ gives

$$
\begin{aligned}
W_{g}= & \Pi_{h}+T_{h}+\Pi_{f}+T_{f}+\frac{1-\gamma}{\gamma} P_{f}^{-\frac{\gamma}{1-\gamma}} \\
= & \frac{1-\gamma}{\gamma} P_{f}^{-\frac{\gamma}{1-\gamma}}+\int_{0}^{N_{f}}\left[\frac{1}{\sigma} p_{f}(j)^{1-\sigma} P_{f}^{\sigma-\frac{1}{1-\gamma}}-w F_{f}\right] d j \\
& +\int_{0}^{n^{c}}\left[\frac{1}{\sigma} p_{I}(i)^{1-\sigma} P_{f}^{\sigma-\frac{1}{1-\gamma}}-w F_{I}\right] d i+\int_{n^{c}}^{N}\left[\frac{1}{\sigma} p_{E}(i)^{1-\sigma} P_{f}^{\sigma-\frac{1}{1-\gamma}}-w F_{E}\right] d i \\
& +\theta_{I}\left(\delta-\tau w_{h}\right)\left(\frac{t_{h}-t_{e}}{1-t_{e}}\right) \int_{0}^{n^{c}} a(i) p_{I}(i)^{-\sigma} P_{f}^{\sigma-\frac{1}{1-\gamma}} d i
\end{aligned}
$$


The first-order condition with respect to $t_{r}$ reads

$$
\begin{aligned}
\frac{\partial W_{g}}{\partial t_{r}}= & -P_{f}^{-\frac{\gamma}{1-\gamma}-1} \frac{\partial P_{f}}{\partial t_{r}}+\left(\frac{\pi_{I}\left(n^{c}\right)}{1-t_{e}}-\frac{\pi_{E}\left(n^{c}\right)}{1-t_{h}}\right) \frac{\partial n^{c}}{\partial t_{r}} \\
& +\theta_{I}\left(\delta-\tau w_{h}\right)\left(\frac{t_{h}-t_{e}}{1-t_{e}}\right) a_{I}^{c} p_{I}\left(n^{c}\right)^{-\sigma} P_{f}^{\sigma-\frac{1}{1-\gamma}} \frac{\partial n^{c}}{\partial t_{r}} \\
& +\left(\sigma-\frac{1}{1-\gamma}\right) P_{f}^{\sigma-\frac{1}{1-\gamma}-1} \frac{1}{\sigma}\left[\begin{array}{c}
\left.\int_{0}^{N_{f}} p_{f}(j)^{1-\sigma} d j+\int_{0}^{n^{c}} p_{I}(i)^{1-\sigma} d i\right] \\
+\int_{n^{c}}^{N} p_{E}(i)^{1-\sigma} d i
\end{array}\right] \frac{\partial P_{f}}{\partial t_{r}} \\
& +\int_{0}^{n^{c}} P_{f}^{\sigma-\frac{1}{1-\gamma}} \frac{\partial p_{I}(i)}{\partial t_{r}}\left[\frac{1-\sigma}{\sigma} p_{I}(i)-\sigma \theta_{I}\left(\delta-\tau w_{h}\right) \frac{t_{h}-t_{e}}{1-t_{e}} a(i)\right] p_{I}(i)^{-\sigma-1} d i \\
& -\theta_{I}\left(\delta-\tau w_{h}\right) \frac{1-t_{h}}{\left(1-t_{f}\right)\left(1-t_{r}\right)^{2}} \int_{0}^{n^{c}} a(i) p_{I}(i)^{-\sigma} P_{f}^{\sigma-\frac{1}{1-\gamma}} d i
\end{aligned}
$$

which can be simplified, using $\frac{\partial p_{I}(i)}{\partial t_{r}}=-\frac{\sigma}{\sigma-1} a(i) \theta_{I}(\delta-\tau w) \frac{1-t_{h}}{\left(1-t_{f}\right)\left(1-t_{r}\right)^{2}}$, to

$$
\begin{aligned}
\frac{\partial W_{g}}{\partial t_{r}}= & -\frac{1}{(1-\gamma) \sigma} P_{f}^{-\frac{1}{1-\gamma}} \frac{\partial P_{f}}{\partial t_{r}} \\
& +\frac{t_{h}-t_{e}}{1-t_{e}}\left[\begin{array}{c}
-\frac{1}{\left(1-t_{h}\right)}\left[\pi_{I}\left(n^{c}\right)-\left(1-t_{h}\right) \theta_{I}\left(\delta-\tau w_{h}\right) a_{I}^{c} p_{I}\left(n^{c}\right)^{-\sigma} P_{f}^{\sigma-\frac{1}{1-\gamma}}\right] \frac{\partial n^{c}}{\partial t_{r}} \\
\quad-\int_{0}^{n^{c}} P_{f}^{\sigma-\frac{1}{1-\gamma}}\left[\sigma \theta_{I}\left(\delta-\tau w_{h}\right) a(i) p_{I}(i)^{-\sigma-1} \frac{\partial p_{I}(i)}{\partial t_{r}}\right] d i
\end{array}\right]
\end{aligned}
$$

Provided that $\frac{\partial P_{f}}{\partial t_{r}}>0$, the consumer surplus decreases more than firm profits are increased (first term). The first term in square brackets which captures the effect of the marginal firm's regime switch on global tax revenue is unambiguously positive. The second term in square brackets depicts the effect of the intra-marginal firms' price changes on global tax revenue which is positive, too. Thus, the sign of the whole term depends on the sign of $t_{h}-t_{e}$. 


\section{CESifo Working Paper Series}

for full list see www.cesifo-group.org/wp

(address: Poschingerstr. 5, 81679 Munich, Germany, office@cesifo.de)

2837 Christoph Böhringer and Knut Einar Rosendahl, Green Serves the Dirtiest: On the Interaction between Black and Green Quotas, October 2009

2838 Katarina Keller, Panu Poutvaara and Andreas Wagener, Does Military Draft Discourage Enrollment in Higher Education? Evidence from OECD Countries, October 2009

2839 Giovanni Cespa and Xavier Vives, Dynamic Trading and Asset Prices: Keynes vs. Hayek, October 2009

2840 Jan Boone and Jan C. van Ours, Why is there a Spike in the Job Finding Rate at Benefit Exhaustion?, October 2009

2841 Andreas Knabe, Steffen Rätzel and Stephan L. Thomsen, Right-Wing Extremism and the Well-Being of Immigrants, October 2009

2842 Andrea Weber and Christine Zulehner, Competition and Gender Prejudice: Are Discriminatory Employers Doomed to Fail?, November 2009

2843 Hadi Salehi Esfahani, Kamiar Mohaddes and M. Hashem Pesaran, Oil Exports and the Iranian Economy, November 2009

2844 Ruediger Bachmann and Christian Bayer, Firm-Specific Productivity Risk over the Business Cycle: Facts and Aggregate Implications, November 2009

2845 Guglielmo Maria Caporale, Burcu Erdogan and Vladimir Kuzin, Testing for Convergence in Stock Markets: A Non-Linear Factor Approach, November 2009

2846 Michèle Belot and Jan Fidrmuc, Anthropometry of Love - Height and Gender Asymmetries in Interethnic Marriages, November 2009

2847 Volker Nitsch and Nikolaus Wolf, Tear Down this Wall: On the Persistence of Borders in Trade, November 2009

2848 Jan K. Brueckner and Stef Proost, Carve-Outs Under Airline Antitrust Immunity, November 2009

2849 Margarita Katsimi and Vassilis Sarantides, The Impact of Fiscal Policy on Profits, November 2009

2850 Scott Alan Carson, The Relationship between Stature and Insolation: Evidence from Soldiers and Prisoners, November 2009

2851 Horst Raff and Joachim Wagner, Intra-Industry Adjustment to Import Competition: Theory and Application to the German Clothing Industry, November 2009 
2852 Erkki Koskela, Impacts of Labor Taxation with Perfectly and Imperfectly Competitive Labor Markets under Flexible Outsourcing, November 2009

2853 Cletus C. Coughlin and Dennis Novy, Is the International Border Effect Larger than the Domestic Border Effect? Evidence from U.S. Trade, November 2009

2854 Johannes Becker and Clemens Fuest, Source versus Residence Based Taxation with International Mergers and Acquisitions, November 2009

2855 Andreas Hoffmann and Gunther Schnabl, A Vicious Cycle of Manias, Crashes and Asymmetric Policy Responses - An Overinvestment View, November 2009

2856 Xavier Vives, Strategic Supply Function Competition with Private Information, November 2009

2857 M. Hashem Pesaran and Paolo Zaffaroni, Optimality and Diversifiability of Mean Variance and Arbitrage Pricing Portfolios, November 2009

2858 Davide Sala, Philipp J.H. Schröder and Erdal Yalcin, Market Access through Bound Tariffs, November 2009

2859 Ben J. Heijdra and Pim Heijnen, Environmental Policy and the Macroeconomy under Shallow-Lake Dynamics, November 2009

2860 Enrico Spolaore, National Borders, Conflict and Peace, November 2009

2861 Nina Czernich, Oliver Falck, Tobias Kretschmer and Ludger Woessmann, Broadband Infrastructure and Economic Growth, December 2009

2862 Evžen Kočenda and Martin Vojtek, Default Predictors and Credit Scoring Models for Retail Banking, December 2009

2863 Christian Gollier and Martin L. Weitzman, How Should the Distant Future be Discounted when Discount Rates are Uncertain?, December 2009

2864 Tiberiu Dragu and Mattias Polborn, Terrorism Prevention and Electoral Accountability, December 2009

2865 Torfinn Harding and Beata Smarzynska Javorcik, A Touch of Sophistication: FDI and Unit Values of Exports, December 2009

2866 Matthias Dischinger and Nadine Riedel, There's no Place like Home: The Profitability Gap between Headquarters and their Foreign Subsidiaries, December 2009

2867 Andreas Haufler and Frank Stähler, Tax Competition in a Simple Model with Heterogeneous Firms: How Larger Markets Reduce Profit Taxes, December 2009

2868 Steinar Holden, Do Choices Affect Preferences? Some Doubts and New Evidence, December 2009 
2869 Alberto Asquer, On the many Ways Europeanization Matters: The Implementation of the Water Reform in Italy (1994-2006), December 2009

2870 Choudhry Tanveer Shehzad and Jakob De Haan, Financial Reform and Banking Crises, December 2009

2871 Annette Alstadsæter and Hans Henrik Sievertsen, The Consumption Value of Higher Education, December 2009

2872 Chris van Klaveren, Bernard van Praag and Henriette Maassen van den Brink, Collective Labor Supply of Native Dutch and Immigrant Households in the Netherlands, December 2009

2873 Burkhard Heer and Alfred Maußner, Computation of Business-Cycle Models with the Generalized Schur Method, December 2009

2874 Carlo Carraro, Enrica De Cian and Massimo Tavoni, Human Capital Formation and Global Warming Mitigation: Evidence from an Integrated Assessment Model, December 2009

2875 André Grimaud, Gilles Lafforgue and Bertrand Magné, Climate Change Mitigation Options and Directed Technical Change: A Decentralized Equilibrium Analysis, December 2009

2876 Angel de la Fuente, A Mixed Splicing Procedure for Economic Time Series, December 2009

2877 Martin Schlotter, Guido Schwerdt and Ludger Woessmann, Econometric Methods for Causal Evaluation of Education Policies and Practices: A Non-Technical Guide, December 2009

2878 Mathias Dolls, Clemens Fuest and Andreas Peichl, Automatic Stabilizers and Economic Crisis: US vs. Europe, December 2009

2879 Tom Karkinsky and Nadine Riedel, Corporate Taxation and the Choice of Patent Location within Multinational Firms, December 2009

2880 Kai A. Konrad, Florian Morath and Wieland Müller, Taxation and Market Power, December 2009

2881 Marko Koethenbuerger and Michael Stimmelmayr, Corporate Taxation and Corporate Governance, December 2009

2882 Gebhard Kirchgässner, The Lost Popularity Function: Are Unemployment and Inflation no longer Relevant for the Behaviour of Germany Voters?, December 2009

2883 Marianna Belloc and Ugo Pagano, Politics-Business Interaction Paths, December 2009 
2884 Wolfgang Buchholz, Richard Cornes and Dirk Rübbelke, Existence and Warr Neutrality for Matching Equilibria in a Public Good Economy: An Aggregative Game Approach, December 2009

2885 Charles A.E. Goodhart, Carolina Osorio and Dimitrios P. Tsomocos, Analysis of Monetary Policy and Financial Stability: A New Paradigm, December 2009

2886 Thomas Aronsson and Erkki Koskela, Outsourcing, Public Input Provision and Policy Cooperation, December 2009

2887 Andreas Ortmann, "The Way in which an Experiment is Conducted is Unbelievably Important": On the Experimentation Practices of Economists and Psychologists, December 2009

2888 Andreas Irmen, Population Aging and the Direction of Technical Change, December 2009

2889 Wolf-Heimo Grieben and Fuat Şener, Labor Unions, Globalization, and Mercantilism, December 2009

2890 Conny Wunsch, Optimal Use of Labor Market Policies: The Role of Job Search Assistance, December 2009

2891 Claudia Buch, Cathérine Tahmee Koch and Michael Kötter, Margins of International Banking: Is there a Productivity Pecking Order in Banking, too?, December 2009

2892 Shafik Hebous and Alfons J. Weichenrieder, Debt Financing and Sharp Currency Depreciations: Wholly vs. Partially Owned Multinational Affiliates, December 2009

2893 Johannes Binswanger and Daniel Schunk, What is an Adequate Standard of Living during Retirement?, December 2009

2894 Armin Falk and James J. Heckman, Lab Experiments are a Major Source of Knowledge in the Social Sciences, December 2009

2895 Hartmut Egger and Daniel Etzel, The Impact of Trade on Employment, Welfare, and Income Distribution in Unionized General Oligopolistic Equilibrium, December 2009

2896 Julian Rauchdobler, Rupert Sausgruber and Jean-Robert Tyran, Voting on Thresholds for Public Goods: Experimental Evidence, December 2009

2897 Michael McBride and Stergios Skaperdas, Conflict, Settlement, and the Shadow of the Future, December 2009

2898 Ben J. Heijdra and Laurie S. M. Reijnders, Economic Growth and Longevity Risk with Adverse Selection, December 2009

2899 Johannes Becker, Taxation of Foreign Profits with Heterogeneous Multinational Firms, December 2009 